accessible patient, and another setting out the Gresham Ward questionnaires for elderly patients. Notes on Eliciting and Recording Clinical Information, Oxford University Press, price 50p.

\section{Dictionary of Epilepsy}

Professor H. Gastaut, of the University of Aix-Marseilles, and a group of experts from 16 countries have produced a dictionary of the clinical terms used in this disease. Recommended terms are defined, and so far as possible all known synonyms are included though they are listed separately and crossreferenced. In many cases the reasons for recommending one particular term rather than an alternative are given. The dictionary is published by the W.H.O., and was produced in response to suggestions that international organizations should take the lead in reducing the growing confusion in medical and scientific terminology. Parn I is being issued simultaneously in English, French, and Spanish, and it is hoped to have it in Russian shortly. Part II is to be a multilingual index; it is not yet available.

Dictionary of Epilepsy. Part I: Definitions. H. Gastaut, W.H.O., 1973, price $£ 2 \cdot 50$.

\section{Hospital Advisory Service}

Dr. Eluned Woodford-Williams has been appointed director of the Hospital Advisory Service in suocession to Dr. Alex Baker. Dr. Woodford-Williams is consultant physician in charge of the geriatric services in the Sunderland Hospital Group. From 1966 to 1971 she was a member of the Central Health Services Council.

\section{Private Medical Care}

Over two-thirds of the subscribers to provident schemes for private medical care are in group schemes, usually set up by firms for key employees. The number of persons insured again increased in 1972, reaching a total of 2,169,000. These figures are given by Lee Donaldson Associates in a report for the Department of Health and Social Security.

\section{COMING EVENTS}

Society for Social Medicine.-Annual scientific meeting, 19-21 September, Southampton. Details from the honorary secretary, Dr. A. E. Bennett, 9 Keble Road, Oxford OX1 3QG. (Tel. 53951.)

London Medical Orchestra.-Rehearsals, Tuesdays, 7 p.m., beginning 25 September, Christ Church School, Conway Street, London N.W.1. New members are welcome and particulars are obtainable from Mrs. I. Weir, Hill House, Mount Park Road, Harrow-on-the-Hill, Middx. (Tel. 01422 8762.)

Institute of Sports Medicine.-Symposium, "Medical Aspects of Some Water Sports," 25 September, 6.15 p.m., Royal Society of Medicine, London $W .1$. Fee $£^{2 \cdot 75}$ (including buffet supper). Applications, before 18 September, to the secretary of the institute, Ling House, 10 Nottingham Place, London W1M 4AX. (Tel. 01-486 1303.)

Medical Women's Federation (North-eastern Association).-Open meeting on health service reorganization, "The Ins . . . of Integration," 25 September, 8 p.m., Royal Victoria Infirmary, Newcastle upon Tyne. Details from Dr. Ann M.
Brown, 12 Lindisfarne Road, Newcastle upon Tyne, NE2 2HE. (Tel. 814141.)

Cystic Fibrosis Research Trust.-Honorary medical advisers conference, 28 September, Institute of Child Health, London W.C.1. Details from the C.F.R.T., 5 Blyth Road, Bromley, Kent, BR1 3RS. (Tel. 01-464 7211.)

Final F.R.C.S. Lecture Course.-Wednesdays, 5 p.m. (no charge), 3 October-20 March, Institute of Urology, 172 Shaftesbury Avenue, London WC2H 8JE. Copies and details of the programme from the assistant secretary of the institute (tel. 01-836 5361).

North Tees General Hospital.-Workshop on "Stoma Care," 5 October, 2 p.m. Admission by ticket (free), from Mrs. D. Hall, research secretary, North Tees General Hospital, Stockton-on-Tees, Teesside.

St. George's Hospital and South-west Metropolitan Orthopaedic Training Scheme.Copies and details of the programme, OctoberDecember, are obtainable from the orthopaedic tutor, St. James's Hospital, Sarsfeld Road, Balham, London SW12. (Tel. 01-672 1222.)

Royal Medical Society, Edinburgh.-Copies and details of the programme, October-March, are obtainable from the business convener, R.M.S., 3 Hill Square, Edinburgh EH8 9DR. (Tel. 031-667 8159.)

\section{SOCIETIES AND LECTURES}

For attending lectures marked a fee is charged or a richet is required. Applications should be

Wednesday, 12 September

Royal Frez Hospice.-5.15 p.m., Dr. Bruce Smith: $\alpha$-Fetoprotein in Necplastic and Non-neoplastic

Thursday, 13 September

ST. Josept's Hosprtal, London.-At Mare Street Hackney, 8 p.m., Mrs. S. Hanna: Voluntary Friday, 14 September

Royal CoLlbge of Physictans op London.-At East Anglia University, Norwich, 4.30 p.m.,

\section{B.M.A. ASSOCIATION NOTICES}

\section{Diary of Central Meetings}

SEPTEMBER

10 Mon. Hospital Junior Staffs Group Council (Scotland) (at Drumsheugh Gardens, Edinburgh), 2.15 p.m.

11 Tues. Scottish General Medical Services Committee (at Drumsheugh Gardens, Edinburgh), 10.15 a.m.

12 Wed. General Purposes Committee, 10 a.m 18 Tues. Public Health Committee (Scotland) (at Drumsheugh Gardens, Edinburgh), 10.45 a.m.

19 Wed. Constitution Subcommittee (G.M.S.)

Panel on Health Care Teams (Board of Science and Education), 2 p.m.

19 Wed. Finance Committee, 2.30 p.m

20 Thurs. General Medical Services Committee, $10 \mathrm{a.m}$.

20 Thurs. Negotiating Subcommittee (C.C.H.M.S.), 10 a.m

20 Thurs. Staff Side of Whitley Committee C 21 Fri $\quad 2.30$ p.m

Medico-Legal Subcommittee (C.C.H.M.S.), 10 a.m.

21 Fri. Board of Science and Education, 10.30 a.m.

26 Wed. Scottish Council (at Drumsheugh Gardens, Edinburgh), 10.15 a.m.

26 Wed. Working Group on L.M.C. Contributions (G.M.S.), 10.30 a.m.

26 Wed. Journal Committee, 2 p.m.

27 Thurs. Central Committee for Hospital Medical Services, 10 a.m.

Full-time Medical Teachers and

28 Fri. Full-time Medical Teachers and

28 Fri.\& Annual Postgraduate Meeting,

29 Sat. Guernsey.
OCTOBER

2 Tues. Hospital Junior Staffs Group Council, 10 a.m.

2 Tues. Working Party on Services for the Elderly (Board of Science and Educa-

3 Wed. Council, 10 a.m.

\section{Branch and Division Meetings to be Held}

Blackburn Division.-At education centre, Blackburn Royal Infirmary, Monday, 10 September, 8 p.m., jointly with Pharmaceutical Society, meeting and talk: "Adverse Drug Re-

Bury Division.-At postgraduate institute, Bury General Hospital, Monday, 10 September, 8.45 p.m., a.g.m.

Lancaster Division.-At postgraduate medical centre, Ashton Road, Wednesday, 12 September, 8 p.m., general meeting.

\section{UNIVERSITIES AND COLLEGES}

\section{LONDON}

The title of reader in cardiac pathology has been posts at St. George's Hospital Medical School.

The title of reader in clinical anaesthesia has been conferred on Dr. J. G. Whitwam in respect of his post at the Royal Postgraduate Medical School.

CAMBRIDGP

M.D.-J. M. Temperley, A. H. Sabah.

\section{Corrections}

\section{Smoking Hazards to the Fetus}

We regret that the letter from Dr. R. J. Hickey and others (1 September, p. 501) contained a number of printing errors. The second paragraph should have read as follows:

"At least two hypotheses may explain the smoking/birth weight statistics: (1) cigarette-smoking causes low birth weight, and (2) the smoking behaviour of women and the birth weights of their children are influenced by a common causethe individual genotype ${ }^{6}$ or constitution. In a study reported by Yerushalmy $y^{2}$ the percentages of low-birth-weight infants for women smokers were 6.4 (white) and 12.3 (black) and for nonsmokers 3.2 and 5.8 respectively. Thus the presumed 'harm' of low birth weight was absent for over $87 \%$ of all infants. Hypothesis 2 asserts that infants born to women before they become smokers will generally be smaller than those of non-smokers. This was confirmed $(P<0.01)$ for white and weakly confirmed $(0.05<\mathbf{P}<0.1)$ for black women. Further, hypothesis 2 predicts a lower incidence of low birth weight among the infants of ex-smokers, while smoking, than for those of habitual smokers. This was confirmed for both black and white women $(P<0.02)$. These findings are incompatible with hypothesis 1."

Notice to Authors

When original articles and letters for publication are not submitted exclusively to the British Medical fournal this must be stated. Accepted articles may subsequently be selected for publication in the North American monthly edition.

Correspondence on editorial business should be addressed to the Editor, British Medical fournal, B.M.A. House, Tavistock Square, London WC1H 9JR. Telephone: 01-387 4499. Telegrams: Aitiology, London, W.C.1.

Authors wanting reprints of their articles should notify the Publishing Manager, B.M.A. House, Tavistock Square, WC1H 9JR, on receipt of proofs.

\section{(C) British Medical Journal 1973}

All Rights Reserved. No part of this publication may be reproduced, stored in a retrieval system, or transmitted, in any form or by any means, electronic, mechanical, photocopying, recording or otherwise, without the prior permission of the British Medical fournal. 